\title{
Service Quality of the Higher Vocational Education
}

\author{
DOI: 10.7595/management.fon.2020.0025
}

Abstract:

Research Question: The paper will investigate the service quality of the higher education provided by the higher schools of vocational studies using SERVQUAL methodology. Motivation: The paper will show the characteristics of higher education of vocational studies, and it will point out the significance of creating and maintaining a quality management system in higher education institutions. The new reform of higher education in Serbia and establishment of academies of vocational studies are the main reasons why the question of service quality becomes one of the most important issues for higher education institutions and basis for competitive advantage, better image and reputation. Also, a growing competition on the higher education market and a smaller number of prospective students are also problems which higher vocational schools are faced with. Idea: The goal of this research is to find the differences between expected and perceived service quality. Furthermore, the paper will show if there are differences between perceived service quality among the students of different study years, as well as differences between the students with State scholarship and the self-funded students. Data: The research included 244 students of the first, second, and third years of bachelor studies from higher schools of vocational studies in Novi Sad, significant and the second-largest educational centre in the Republic of Serbia. Tools: Statistical methods used in this paper are frequency analysis, descriptive statistics, while the hypotheses are tested using the paired sample t-test, the independent t-test, and the one-factor variance analysis - ANOVA. Findings: The results of the research show that service quality of higher vocational education does not meet students' expectations (sig. $<0,001)$ and that the gap is negative for all dimensions of service quality (Tangibles (-.32), Reliability (-.52), Responsiveness (-.49), Assurance (-.33), and Empathy $(-.26))$. It is also shown by this research that there are no differences in higher education service quality based on the status of students (sig. $>0.05$ ) and the year of studying (sig.>0.05). Contribution: The results can be used as basis for introducing further measures to improve the quality of service provided by higher vocational institutions.

Keywords: service quality, SERVQUAL, higher education, higher vocational schools, Serbia

JEL Classification: I23, L89

\section{Introduction}

Education is the foundation of development and survival of society together with economic, political, and cultural growth. For more than a decade, the goal of education reforms in Serbia has been the improvement of service quality provided by higher education institutions. Providing high-quality service to satisfy and even exceed not only students' but also other stakeholders' expectations in higher education is the basis of creating competitive advantage of higher education institutions. In that way, institutions are creating a better image, reputation, and attract a larger number of enrolled students. At the same time, the opportunity for cooperation with economic, scientific, education and professional organizations is also raising. Greater mobility, more shared projects, and other aspects, by consequence, improve the quality and the service provided by a higher education institution. 
The trend of decrease in the number of students, an increasing gap between the numbers of planned and those of enrolled students, as well as an increasing competition among higher education institutions in the Republic of Serbia, have influenced the need that students, as primary users of services, have to be considered as consumers (Yousapronpaiboon, 2014). In such an environment, the quality of services provided by higher education institutions is becoming a key factor in differentiating and creating a superior experience of studying (Woodall, Hiller, \& Resnick, 2014; Nixon, Scullion \& Hearn, 2018).

The choice of profession, a field of studies, and higher education institutions are some of the most important decisions individuals have to make during a whole lifetime, and these are made based on a complex set of personal preferences and capacities, but also on information obtained from the external environment. Expectations formed before enrollment are the basis for the evaluation of higher education services in a particular higher education institution. Students' expectations are mainly focused on the quality of study programmes, knowledge and skills applicable in the labour market, a diploma recognized by employers and other higher education institutions, as well as an adequate academic environment (Đonlagic \& Fazlic, 2015).

Service quality is based on students' expectations, as well as on the perceptions of the received service. That is the reason why the essential task of every service organization, including higher education institutions, is to ensure students' satisfaction through the levelling of received and expected services. Higher education institutions can provide higher values for students through further efforts and thus exceed their expectations. This creates students' enthusiasm and higher satisfaction, loyalty, and spread a positive image of the institution.

Quality monitoring in higher education is an obligation of every higher education institution and is possible to achieve through the application of several methods: self-evaluation, peer-review, analysis of statistical data, evaluation of students' knowledge and competences, but also through stakeholder surveys (Harman 1998), where the insight into the student satisfaction is most important. The results obtained in this way represent information of particular benefit to the management of higher education institutions for improving future performance (Khanli, Daneshmandi \& Choobineh, 2014), as well as for creating superior marketing strategies (Gajic, 2012).

Previous studies on the quality of service in higher education in the Republic of Serbia, and especially in the case of vocational education are insufficient. They do not take the students perception as crucial for service quality (Rodic Lukic, 2016), which indicates an incomplete examination of this area and a necessity for the proposed research.

The research into the service quality of higher education and the satisfaction of its primary consumers - the students, is the subject of this paper.

The primary hypothesis of this research is:

$\mathrm{H}_{0}$. There is a difference between expected and perceived quality of service in higher vocational education. From this primary hypothesis, specific hypotheses have been defined:

$\mathrm{H}_{1}$. There is a difference between perceived and expected service in higher education in terms of Tangibles dimension;

$\mathrm{H}_{2}$. There is a difference between perceived and expected service in higher education in terms of Reliability dimension;

$\mathrm{H}_{3}$. There is a difference between perceived and expected service in higher education in terms of Responsiveness dimension;

$\mathrm{H}_{4}$. There is a difference between perceived and expected service in higher education in terms of Assurance dimension;

$\mathrm{H}_{5}$. There is a difference between perceived and expected service in higher education in terms of Empathy dimension.

In addition, previous research has shown that certain socio-demographic characteristics, the students status and the background of students have an impact on satisfaction and perceived quality of service provided by higher education institutions (Akareem \& Hossain, 2016; Douglas et al., 2015; Fajčíková \& Urbancová, 2019). Besides the primary objective of the research, this paper also deals with differences in consumer perception of higher education services based on students' status and the year of studying.

$\mathrm{H}_{6}$. There are differences in perceived quality between the students with the State scholarship and selffunded students. 
$\mathrm{H}_{7}$. There are differences in perceived service quality between students of the first, second, and third years of study.

This paper will show the main features of higher vocational education, and it will indicate the importance of providing a quality management system in higher education institutions. The results of the study will show the current state and level of service quality of higher education of vocational studies, and they can be used as a basis for the further direction of development and activities in the function of raising the quality of service provided by higher vocational institutions.

\section{Quality of Service in Higher Education}

Quality of service in higher education is based on the difference between perceived and expected service (Parasuraman, Zeithaml, \& Berry, 1988). The result of comparing the expected with the realized or received service determines consumers' satisfaction or dissatisfaction with the service.

The Action Plan for The Implementation of The Strategy for Education Development by 2020 (2015) says that quality in higher education is one of the key objectives for the development of education. Responsible for the improvement and development of the quality of higher vocational education in Serbia are the National Entity for Accreditation and Quality Assurance in Higher Education in Serbia, the National Council and Conference of Academies and Higher Schools. Higher vocational schools in Serbia have the obligation of the external quality check of the higher education institution implemented by the Commission for Accreditation. Furthermore, higher education institutions have the obligation of performing self-evaluation and grading the quality of their curricula, classes, and work conditions. The education reform brings about new things because the new Law of Higher Education (2018) introduces a direct influence of international factors on the quality. It is represented through the anticipation that the teacher of higher education institutions in Serbia, but also the teachers who have specific titles in the higher education institutions that are not in the country, can be on the reviewers' list in the accreditation process.

In order to increase the quality of vocational education, a new reform of higher vocational education in Serbia started in 2018, also including higher vocational schools in Novi Sad. The new reform of the Government of Serbia includes the formation of the academies of vocational studies. This can be achieved either by the transformation of the existing higher schools of vocational studies or by merging several higher schools of vocational studies into a new higher education institution - the Academy of Vocational Studies. Numerous schools have already been joined into academies, yet this process has not been finalized to this day.

The ever-growing competition on the higher education market, the opening of many private higher education institutions, a smaller number of potential students compared to that of a decade ago, labour market requests in terms of new jobs and professions, the need for internationalization, the lack of competent personnel for working in vocational schools and the insufficient connection between vocational education institutions and the labour market and practice - all these create the need for constant changes and the increased care for students. That being said, the service quality of higher schools is of crucial importance for achieving student satisfaction, which is why the research of the level of satisfaction with the higher education service is of great importance.

The significance of the service quality in higher education is seen in its direct correlation with students' satisfaction (Dado et al., 2012; Weerasinghe \& Fernando, 2018), and their loyalty (Darawong \& Sandmaung, 2019). This is the basis for making a profit (Șerban \& Stoian, 2019) and for creating the positive image and reputation (Merchant et al., 2015), and it is one of the key factors for the students when it comes to enrolling at the competitive institution. If the expectations of students are not met, there is dissatisfaction, and if the perceived quality is low, these can all have severe consequences on the number of enrolled students, on spreading the negative image among other students, which can lead to the decline of the institution.

Service quality in higher education has been the main subject of research of many authors (e.g., Dado et al., 2012; Latif et al., 2019; Teeroovengadum et al, 2019; Hwang \& Choi, 2019; Bsharat, \& Ibrahim, 2020). In Serbia there are also many studies that focus on service quality and student satisfaction (e.g., Dado, 2012; Rodic Lukic, 2016; Jevremov, Lungulov \& Dinic 2016, Nesic et al., 2017; Milojevic \& Radosavljevic, 2019) and a smaller number of studies that focus on students of higher schools of vocational studies (Vranjes, Gasevic \& Drinic, 2014; Josanov-Vrgovic et al., 2020; Damnjanovic, Jovicic Vukovic, \& Papic-Blagojevic, 2020). 
There are different research methodologies for testing the service quality and student satisfaction in higher education: SERVQUAL (Parasuraman et al, 1988), SERVPERF (Cronin \& Taylor, 1992), HedPERF (Abdullah, 2005), EduQUAL (Mahapatra \& Khan, 2007), PHEd (Sultan \& Wong, 2010), PGSQUAL (Govender \& Ramroop, 2012), HiEDQUAL (Annamdevula \& Bellamkonda, 2012), HESQUAL (Teeroovengadum, Kamalanabhan \& Seebaluck, 2016), HiEduQual (Latif et al., 2019), UnivQual (Marimon et al., 2019). The instruments mentioned above are differentiated in terms of concept, dimensions, and the numbers of variables. The SERVQUAL is one of the most frequently used models, and it measures the quality of service in higher education by using five dimensions of quality (reliability, responsiveness, assurance, empathy and tangibles (Legcevic, 2009; Shekarchizadeh, Rasli, \& Hon-Tat et al., 2011).

\section{Methodology}

The research included 244 students of the first, second, and third years of bachelor studies from higher schools of vocational studies in Novi Sad.

This research used a pen and paper survey, which had two parts. The survey's first part focused on students' socio-demographic data (Table 1). The second part included the usage of SERVQUAL methodology developed and tested by Parasuraman, Zeithaml, and Berrydevel (1988; 1991; 1994). In this study, the adopted version of the SERVQUAL model in higher education was used (Rodic Lukuc, 2016). In the first part, the survey included 29 questions related to the expectations the student had. In comparison, the second part included 29 questions related to their perceptions of the service quality of the higher education institution they are enrolled at.

Table 1: Socio-demographic characteristics of students

\begin{tabular}{|l|l|c|c|}
\hline \multicolumn{1}{|c|}{ Variable } & \multicolumn{1}{|c|}{ Category } & Frequency & Valid Percent \\
\hline \multirow{2}{*}{ Gender } & Male & 84 & 34.6 \\
\cline { 2 - 4 } & Female & 159 & 65.4 \\
\hline \multirow{2}{*}{ Place of residence } & Rural & 89 & 36.9 \\
\cline { 2 - 4 } & Urban & 152 & 63.1 \\
\hline \multirow{3}{*}{ Year of study } & First & 88 & 36.1 \\
\cline { 2 - 4 } & Second & 105 & 43 \\
\cline { 2 - 4 } & Third & 51 & 20.9 \\
\hline \multirow{2}{*}{ Students' status } & State scholarship & 176 & 72.1 \\
\cline { 2 - 4 } & Self-funding & 68 & 27.9 \\
\hline
\end{tabular}

Source: Calculations of the authors

The students were required to state how much they agree with the statements on the Likert scale ranging from 1 (the lowest value) to 5 (the highest value). The levels were divided into five dimensions:

- Tangibles - refer to the material elements of the service (nine items);

- Reliability - refer to the ability of the higher education institution to adequately respond to requests, without errors and on time (four items);

- Responsiveness - refer to the readiness of a higher education school to give quick service and to provide information about the time frames of the service (six items);

- Assurance - refer to the material and physical safety, as well as to the knowledge of the employees, the way they are addressing students and the level of trust the students have in the school (five items);

- Empathy - refers to service personalization in line with consumers' requests and a better understanding of students' needs (five items).

Furthermore, the total of the expected and perceived quality is calculated. It included all 29 items that refer to perceptions, as well as 29 items that relate to the expectations of students.

The analysis of the research results included the calculation of the gap between the average values of the expected level of service and average values of perceived service quality. The results show whether the level of received service is below the expected service, whether it was in the line of expected service or whether it exceeded the expectations of students.

The data were analyzed using frequency analysis, descriptive statistics. In contrast, the paired sample ttest, the independent t-test, and the one-factor variance analysis - ANOVA, were used for testing the hypothesis. 


\section{Results and Discussion}

The results of the differences between perception and expectations of students in terms of the quality of higher education services were obtained using paired sample T-test.

In the first part of the research, all dimensions of the SERVQUAL questionnaire were analyzed, and the hypothesis of the existence of differences between the expected and perceived quality was confirmed. It indicates a need for a more significant investment in the quality of service provided at higher education institutions. The process of accreditation and self-evaluation of higher education requires constant improvement and development of human, spatial and educational resources. Also, the opinion of students, in addition to existing quality surveys, must be strengthened with additional research.

The results presented in Table 2 showed that there was a statistically significant difference within the pair results (Sig. <0.05), which confirms the hypotheses $\mathrm{H} 1-\mathrm{H} 5$. This gap is negative for all dimensions, which shows that the services were of insufficient quality, and did not meet the expectations of students. The most significant differences were recorded with the Reliability and Responsiveness dimensions, whereas the smallest negative gap was filed with the Empathy dimension. Based on that, it can be concluded that the students were the least satisfied with the ability and readiness of the higher education institution to respond to their requests and provide the necessary information on time and with as few mistakes as possible. On the other hand, the existence of empathy and a better understanding of students' individual needs has made this dimension the best evaluated.

According to similar research, Khanli, Daneshmandi \& Choobineh (2014) showed that the smallest negative gap is found in the Responsiveness dimension, whereas the most significant difference was in the Empathy dimension (e.g., Legcevic, 2009; Shekarchizadeh et al., 2011). Other studies showed that the smallest negative gap is in the case of the Reliability dimension (e.g., Legcevic, 2009) and Assurance (Dado et al., 2012). Compared to the research of students at the University of Novi Sad (Rodic Lukic, 2016), the results were similar, with the most significant gap being recorded with the Reliability dimension, which is in line with this research, while the smallest difference was found in the Tangibles dimension. In order to examine the size of the influence of the observed variables, in Table 2 shows the effect size for paired samples t-test (according to Cohen (1988) values up to 0.01 show poor effect, up to 0.06 show medium effect, and over 0.14 show a significant effect). Bearing in mind that the effect was estimated as significant for all data pairs, we conclude that there is a significant difference between the perceived and expected quality for all observed dimensions. It confirmed the $\mathrm{H} 1-\mathrm{H} 5$ hypotheses once again.

Table 2: Paired Sample T-Test of SERVQUAL dimensions

\begin{tabular}{|c|c|c|c|c|c|c|c|c|}
\hline \multicolumn{2}{|l|}{$\begin{array}{l}\text { Servqual dimensions - } \\
\text { Pairs }\end{array}$} & M & $\mathbf{N}$ & SD & $\mathbf{t}$ & Sig. & $\begin{array}{l}\text { Servqual } \\
\text { gap and } \\
\text { rank }\end{array}$ & $\begin{array}{l}\text { Effect size } \\
\text { and result }\end{array}$ \\
\hline \multirow{2}{*}{ Tangibles } & $P$ & 4.0119 & 243 & .58408 & \multirow{2}{*}{-7.900} & \multirow{2}{*}{.000} & \multirow{2}{*}{$-.32099(3)$} & \multirow{2}{*}{$\begin{array}{c}0.23 \\
\text { (large effect) }\end{array}$} \\
\hline & $\mathrm{E}$ & 4.3329 & 243 & .48511 & & & & \\
\hline \multirow{2}{*}{ Reliability } & $\mathrm{P}$ & 4.0021 & 243 & .73258 & \multirow{2}{*}{-9.972} & \multirow{2}{*}{.000} & \multirow{2}{*}{$-.51749(1)$} & \multirow{2}{*}{$\begin{array}{c}0.28 \\
\text { (large effect) }\end{array}$} \\
\hline & $E$ & 4.5195 & 243 & .48413 & & & & \\
\hline \multirow{2}{*}{ Responsiveness } & $\mathrm{P}$ & 4.0412 & 243 & .66539 & \multirow{2}{*}{-10.500} & \multirow{2}{*}{.000} & \multirow{2}{*}{$-.49246(2)$} & \multirow{2}{*}{$\begin{array}{c}0.30 \\
\text { (large effect) }\end{array}$} \\
\hline & $\mathrm{E}$ & 4.5336 & 243 & .46934 & & & & \\
\hline \multirow{2}{*}{ Assurance } & $\mathrm{P}$ & 4.2017 & 236 & .85810 & \multirow{2}{*}{-5.589} & \multirow{2}{*}{.000} & \multirow{2}{*}{$-.32966(4)$} & \multirow{2}{*}{$\begin{array}{c}0.23 \\
\text { (large effect) }\end{array}$} \\
\hline & $E$ & 4.5314 & 236 & .43451 & & & & \\
\hline \multirow{2}{*}{ Empathy } & $\mathrm{P}$ & 3.9802 & 243 & .68895 & \multirow{2}{*}{-5.530} & \multirow{2}{*}{.000} & \multirow{2}{*}{$-.26255(5)$} & \multirow{2}{*}{$\begin{array}{c}0.14 \\
\text { (large effect) }\end{array}$} \\
\hline & $E$ & 4.2428 & 243 & .62679 & & & & \\
\hline \multirow{2}{*}{ Service quality Total } & $\mathrm{P}$ & 4.0429 & 233 & .56889 & \multirow{2}{*}{-10.004} & \multirow{2}{*}{.000} & & \\
\hline & $E$ & 4.4191 & 233 & .40598 & & & & \\
\hline
\end{tabular}

$d f=342$, P-Perceptions, E-Expectations

Source: Calculations of the authors

Moreover, the gap was calculated between the total of perceived quality and the total of expected quality of the service of higher education (Table 2). The result has shown that the average value of the expected service $(M=4.41)$ is higher than the received service $(M=4.04)$ which further shows that there is a statistically significant difference (Sig. $<0.05$ ), and that there is a negative gap ( $\mathrm{M}$ perceived-M expected $=-0.37$ ). The results show that the perceived service quality is not in line with the expectations, which confirms hypothesis HO. These results are in line with the results of the previous studies (e.g., Legcevic, 2009; Dado et al., 2012; Shekarchiza et al., 2011; llyas et al., 2013, Rodic Lukic, 2016). 
Table 3: Independent t-test according to the status of students

\begin{tabular}{|c|c|c|c|c|c|c|}
\hline Variable & Student status & $\mathbf{N}$ & M & SD & $\mathbf{t}$ & Sig. \\
\hline \multirow{2}{*}{ Tangibles } & State scholarship & 176 & 4.0385 & .57960 & \multirow{2}{*}{1.050} & \multirow{2}{*}{.295} \\
\hline & self-funded & 68 & 3.9510 & .59461 & & \\
\hline \multirow{2}{*}{ Reliability } & State scholarship & 176 & 4.0028 & .76904 & \multirow{2}{*}{-.047} & \multirow{2}{*}{.963} \\
\hline & self-funded & 68 & 4.0074 & .63034 & & \\
\hline \multirow{2}{*}{ Responsiveness } & State scholarship & 176 & 4.0341 & .69014 & \multirow{2}{*}{-.337} & \multirow{2}{*}{.736} \\
\hline & self-funded & 68 & 4.0662 & .59791 & & \\
\hline \multirow{2}{*}{ Assurance } & State scholarship & 173 & 4.1919 & .93892 & \multirow{2}{*}{-.114} & \multirow{2}{*}{.909} \\
\hline & self-funded & 65 & 4.2062 & .59158 & & \\
\hline \multirow{2}{*}{ Empathy } & State scholarship & 176 & 3.9784 & .67966 & \multirow{2}{*}{-.130} & \multirow[b]{2}{*}{.897} \\
\hline & self-funded & 68 & 3.9912 & .71440 & & \\
\hline \multirow{2}{*}{$\begin{array}{c}\text { Service quality } \\
-\quad \text { Total }\end{array}$} & State scholarship & 173 & 4.0480 & .58479 & \multirow{2}{*}{.278} & \multirow{2}{*}{.781} \\
\hline & Self-funded & 65 & 4.0249 & .53157 & & \\
\hline
\end{tabular}

Source: Calculations of the authors

Further analysis included the perception of the quality of service among students depending on their status, that is, whether they have state scholarships or they are self-funded.

The independent t-test results show that at the level Sig. $<0.05$, there are no significant statistical differences between dimensions' average values. These measures were used to measure the quality of service between self-funded students and students with state scholarships (Table 3) and hypothesis $\mathrm{H} 6$ is rejected. The previous study done on the students of the University of Novi Sad showed that there were statistically significant differences in the perceptions of service quality in case of all variables among the students with both the state scholarship and self-funded students, except when it comes the Tangibles variable (Rodic Lukic, 2016), where the students with the state scholarship perceived that the service is of higher quality than the students who were self-funded. The other research by Akareem \& Hossain (2016) showed that students with scholarships who received scholarships based on their success during studies had higher expectations in terms of service quality than those who did not have scholarships.

The last hypothesis is tested using the one-factor variance analysis - ANOVA, to find the differences in the perceived service quality in higher education among three groups of students, classed on the basis of the year of studying. The results are shown in Table 4.

Table 4: ANOVA test according to the year of studying

\begin{tabular}{|c|c|c|c|c|c|}
\hline Variable - Year of studying & $\mathbf{N}$ & $\mathbf{M}$ & SD & $\mathbf{F}$ & Sig \\
\hline First year & 88 & 3.9608 & .48375 & \multirow[t]{4}{*}{2.231} & \multirow[t]{4}{*}{.110} \\
\hline Second year & 100 & 4.0476 & .62379 & & \\
\hline Third year & 50 & 4.1724 & .58228 & & \\
\hline Total & 238 & 4.0417 & .56973 & & \\
\hline
\end{tabular}

Source: Calculations of the authors

Based on the results, it is established that there are no statistically significant differences at the level Sig $<0.05$ among the three student groups - the students of the first, the second and third years of study, which is why the hypothesis $\mathrm{H} 7$ is rejected. The research results are in line with the results of the studies by the authors llyas et al. (2013) and Corts et al. (2000) and are not in accordance with the study of the author Douglas et al. (2006) and Jevremov, et al. (2016). The third-year students graded the quality of service with the highest average value $(M=4.17)$ compared to other years. At the same time, the least satisfied were the students in the first year $(M=3.9)$, which indicates that satisfaction is increased by the year of study. 
Conslusion

Until the implementation of the Bologna Process and the new conditions at the higher education market, the question of quality in higher education, even though it was essential, wasnot the key issue for the higher education institutions for many years. With the education reforms, the opening of many private higher education institutions, the decrease in the number of students, and the application for the resources with the international funds have become and are the crucial points that every higher education institution is faced with. The new possibilities of participation in the academic exchange, the lack of expert teaching staff, new requests of the labour market, and other changed circumstances that have happened in the last ten years are also in focus. On the other hand, the higher education institutions are constantly under pressure and expectations of the students who demand added value, so the question of quality and the constant improvement of the service of higher education becomes a key issue.

The development of vocational education and raising the competencies of teachers employed in higher vocational schools are part of the National Strategy for Education Development. Its implementation is envisaged by individual actions defined in the Action Plan for the implementation of the strategy. The results presented so far have shown that this part of higher education has not been paid sufficient attention and that further investment is necessary to raise the quality of service at all levels.

At the same time, the research of the analysis of the quality in higher education in the Republic of Serbia generally has not had the students of higher schools of vocational studies in its focus. Therefore, the gap in this segment has been filled with this research.

The results show that there is a negative gap between the expectation and the perception of the students. They also show that it is necessary to work on the improvement of all the aspects of the service. The effect size, according to Cohen's criteria, is proven as significant, and the authors believe that the issue of service quality in higher vocational schools, especially in the field of providing accurate and timely information, needs additional attention. Strengthening the digital competencies of support services, greater digitalization of the teaching process, and greater transparency of relevant information could contribute to greater student satisfaction with the offered quality.

Moreover, it shows that there are no differences in the perception of the service quality between the state scholarship students and self-funded students. The results have shown that the perceived service quality is not statistically different from study year to study year. Still, it has also shown that the rating of the quality of service increases by the year of study.

The research results provide relevant information to the management of the higher educational institutions with the feedback on whether the requests and the students' expectations were met. It can give information about the current level of satisfaction and the quality of service, or dissatisfaction of students as the most essential and primary consumers of the service.

The results show that improvement of all the aspects of the service quality is needed so that the image and the reputation of the higher schools of vocational studies in Novi Sad and Serbia can be improved. Higher market orientation, flexibility, the measures for the improvement of quality, and the creation of added value for the students are of crucial importance to the institutions that this research deals with.

The research has certain limitations in terms of the size of the sample, which is why the generalization of the results is not recommended. Furthermore, it would be useful to provide longitudinal research so that the information on the service quality and the satisfaction of students would be practically and scientifically more relevant. It would be of great interest to the higher education institutions, government entities, and the creators of strategy and the politics of quality in higher education. This way, both internal and external issues can be dealt with as it can provide more advanced internal and external mechanisms for the management of quality.

\section{Acknowledgments}

This research has been supported by the project Professional Development of Vocational Education Teachers with European Practices (Pro-VET), no. 598698-EPP-1-2018-1-FI-EPPKA2-CBHE-JP funded by EACEA, EU, and project no. 142-4512737/2018-02-1, supported by the Provincial secretary for higher education and scientific research of AP Vojvodina. 


\section{REFERENCES}

[1] Abdullah, F. (2005). HEdPERF versus SERVPERF: The quest for ideal measuring instrument of service quality in higher education sector. Quality Assurance in education, 13(4), 305-328. DOI: 10.1108/09684880510626584

[2] Akareem, H. S., \& Hossain, S. S. (2016). Determinants of education quality: what makes students' perception different?. Open Review of Educational Research, 3(1), 52-67. DOI: 10.1080/23265507.2016.1155167

[3] Akcioni plan za sprovođenje strategije razvoja obrazovanja u Srbiji do 2020. godine (2015).

[4] Annamdevula, S., \& Bellamkonda, R. S. (2012). Development of HiEdQUAL for Measuring ServiceQuality in Indian Higher Education Sector. International Journal of Innovation, Management and Technology, 3(4), 412. DOI: 10.7763/ijimt.2012.v3.265

[5] Bsharat, M., \& Ibrahim, O. (2020). Quality of service acceptance in cloud service utilization: An empirical study in Palestinian higher education institutions. Education and Information Technologies, 25(2), 863888. doi: 10.1007/s10639-019-09987-z

[6] Cohen, J. (1988). Statistical power analysis for the behavioral sciences (2nd ed.). Hillsdale, NJ: Erlbaum.

[7] Corts, D. P., Lounsbury, J. W., Saudargas, R. A., \& Tatum, H. E. (2000). Assessing undergraduate satisfaction with an academic department: A method and case study. College Student Journal, 34(3), 399-399.

[8] Cronin Jr, J. J., \& Taylor, S. A. (1992). Measuring service quality: a reexamination and extension. Journal of marketing, 56(3), 55-68. DOI: 10.2307/1252296

[9] Dado, J., Taborecka-Petrovicova, J., Cuzovic, S., \& Rajic, T. (2012). An empirical examination of the relationships between service quality, satisfaction and behavioral intentions in higher education setting. Serbian Journal of Management, 7(2), 203-218. DOI: 10.5937/sjm7-1245

[10] Damnjanovic, J.Jovicic Vukovic, A. Papic-Blagojevic, N. (2020, february). Kvalitet usluge visokog strukovnog obrazovanja kroz primer dobre prakse, Paper presented at the XXVI Skup Trendovi razvoja: "Inovacije u modernom obrazovanju", 454-457.

[11] Darawong, C., \& Sandmaung, M. (2019). Service quality enhancing student satisfaction in international programs of higher education institutions: a local student perspective. Journal of Marketing for Higher Education, 1-16. DOI: 10.1080/08841241.2019.1647483

[12] Douglas, J., Douglas, A., \& Barnes, B. (2006). Measuring student satisfaction at a UK university. Quality assurance in education, 14(3), 251-267. DOI: 10.1108/09684880610678568

[13] Douglas, J. A., Douglas, A., McClelland, R. J., \& Davies, J. (2015). Understanding student satisfaction and dissatisfaction: an interpretive study in the UK higher education context. Studies in Higher Education, 40(2), 329-349. DOI: 10.1080/03075079.2013.842217

[14] Đonlagić, S., \& Fazlić, S. (2015). Quality assessment in higher education using the SERVQUAL model. Management: journal of contemporary management issues, 20(1), 39-57.

[15] Fajčíková, A., \& Urbancová, H. (2019). Factors Influencing Students' Motivation to Seek Higher Education-A Case Study at a State University in the Czech Republic. Sustainability,11(17), 4699. DOI: $10.3390 /$ su11174699

[16] Gajić, J. (2012). Importance of marketing mix in higher education institutions. Singidunum journal of applied sciences, 9(1), 29-41. DOI: 10.5937/sjas1201029g

[17] Govender, K. K., \& Ramroop, S. (2012). The relationship among the postgraduate research climate, service experience, quality and satisfaction. African Journal of Business Management, 6(30), 89178926. doi: $10.20853 / 27-1-231$

[18] Hwang, Y. S., \& Choi, Y. K. (2019). Higher education service quality and student satisfaction, institutional image, and behavioral intention. Social Behavior and Personality: an international journal, 47(2), 1-12. DOI: $10.2224 / \mathrm{sbp} .7622$

[19] Ilyas, A., Nasir, H., Hussain, F., Malik, M. R., Munir, S., \& Sarwar, Z. (2013). Evaluating business schools service quality using SERVQUAL model. Journal of Basic Applied Scientific Research, 3(5), 710-6.

[20] Jevremov D, T., Lungulov, B., \& Dinic, B. (2016). Zadovoljstvo studenata kvalitetom nastave: efekti godine studija i akademskog postignuca. Nastava i vaspitanje, 65(3), 491-508.

[21] Josanov-Vrgovic, I., Jovicic Vukovic, A., Papic-Blagojevic, N., \& Bolesnikov, D. (2020). Analysis of Quality of Services in Higher Education Institutions. In Handbook of Research on Creating Sustainable Value in the Global Economy. IGI Global. 349-365.

[22] Khanli, M. R., Daneshmandi, H., \& Choobineh, A. (2014). The students' viewpoint on the quality gap in educational services. Journal of Advances in Medical Education \& Professionalism, 2(3), 114.

[23] Latif, K. F., Latif, I., Farooq Sahibzada, U., \& Ullah, M. (2019). In search of quality: measuring higher education service quality (HiEduQual). Total Quality Management \& Business Excellence,30(7-8), 768791. DOI: $10.1080 / 14783363.2017 .1338133$ 
[24] Law on Higher Education (Official Gazette of RS, No 88/2017, 27/2018 - other law and 73/2018)

[25] Legcevic, J. (2009). Quality gap of educational services in viewpoints of students, Ekonomska misao i praksa, (2), 279-298

[26] Mahapatra, S. S., \& Khan, M. S. (2007). A framework for analysing quality in education settings. European Journal of Engineering Education, 32(2), 205-217. DOI: 10.1080/03043790601118606

[27] Marimon, F., Mas-Machuca, M., Berbegal-Mirabent, J., \& Llach, J. (2019). UnivQual: a holistic scale to assess student perceptions of service quality at universities. Total Quality Management \& Business Excellence, 30(1-2), 184-200. DOI: 10.1080/14783363.2017.1302795

[28] Merchant, A., Rose, G. M., Moody, G., \& Mathews, L. (2015). Effect of university heritage and reputation on attitudes of prospective students. International Journal of Nonprofit and Voluntary Sector Marketing, 20(1), 25-37. doi: 10.1002/nvsm.1515

[29] Milojevic, R., \& Radosavljevic, M. (2019). Assessment of higher education service quality: integration of servqual model and ahp method. TEME, 557-577. DOI: 10.22190/teme190131034m

[30] Nesic, M., Ahmetovic, Z., Srdic, V., \& Badric, M. (2017). Evaluation of the HEDUQUAL Scale Intended for Assessment of Students' Perceptions of Service Quality in Higher Education Institution in Vojvodina. Croatian Journal of Education: Hrvatski casopis za odgoj i obrazovanje, 19(3), 867-889. DOI: 10.15516/cje.v19i3.2573

[31] Nixon, E., Scullion, R., \& Hearn, R. (2018). Her majesty the student: marketised higher education and the narcissistic (dis)satisfactions of the student-consumer. Studies in Higher Education, 43(6), 927-943. doi: 10.1080/03075079.2016.1196353

[32] Parasuraman, A., Zeithaml, V. A., \& Berry, L. L. (1988). Servqual: A multiple-item scale for measuring consumer perception. Journal of retailing, 64(1), 12

[33] Parasuraman, A., Berry, L.L. and Zeithaml, V.A. (1991). Refinement and reassessment of the SERVQUAL scale. Journal of Retailing 67 (4), 420-450.

[34] Parasuraman, A., Zeithaml, V.A. and Berry, L.L. (1994). Reassessment of expectations as a comparison standard in measuring service quality: implications for further research. Journal of Marketing 58 (1), 111-124. DOI: $10.1177 / 002224299405800109$

[35] Rodic Lukic, V. (2016). Kvalitet usluge u funkciji satisfakcije i namera korisnika u ostvarivanju marketing performansi visokoobrazovnih institucija na Zapadnom Balkanu doktorska disertacija, Univerzitet u Novom Sadu, Ekonomski fakultet, Subotica.

[36] Șerban, V., \& Stoian, E. (2019). Quality assessment in higher education based on SERVQUAL model. Scientific Papers Series-Management, Economic Engineering in Agriculture and Rural Development, 19(2), 427-436.

[37] Shekarchizadeh, A., Rasli, A., \& Hon-Tat, H. (2011). SERVQUAL in Malaysian universities: perspectives of international students. Business Process Management Journal, 17(1), 67-81. DOI: $10.1108 / 14637151111105580$

[38] Sultan, P. \& Yin Wong, H. (2010). Service quality in higher education-a review and research agenda. International Journal of Quality and Service Sciences, 2(2), 259-272. doi: 10.1108/17566691011057393

[39] Teeroovengadum, V., Kamalanabhan, T. J., \& Seebaluck, A. K. (2016). Measuring service quality in higher education. Quality Assurance in Education, 24(2), 244-258. DOI:10.1108/QAE-06-2014-0028

[40] Teeroovengadum, V., Nunkoo, R., Gronroos, C., Kamalanabhan, T. J., \& Seebaluck, A. K. (2019). Higher education service quality, student satisfaction and loyalty. Quality Assurance in Education, 27(4), 427445. DOI:10.1108/QAE-01-2019-0003

[41] Vranjes, M. Gasevic, D. Drinic D. (2014). Analiza elemenata kvaliteta usluga u visokom obrazovanju, Marketing, 45 (3), 213-222.

[42] Weerasinghe, I. M. S., \& Fernando, R. L. S. (2018). Critical factors affecting students' satisfaction with higher education in Sri Lanka. Quality Assurance in Education, 26(1), 115-130. DOI: 10.1108/qae-042017-0014

[43] Woodall, T., Hiller, A., \& Resnick, S. (2014). Making sense of higher education: students as consumers and the value of the university experience. Studies in Higher Education, 39(1), 48-67. DOI: $10.1080 / 03075079.2011 .648373$

[44] Yilmaz, V., Ari, E., \& Gürbüz, H. (2018). Investigating the relationship between service quality dimensions, customer satisfaction and loyalty in Turkish banking sector: an application of structural equation model. International Journal of Bank Marketing, 36(3), 423-440. DOI: 10.1108/ijbm-02-2017-0037

[45] Yousapronpaiboon, K. (2014). SERVQUAL: Measuring higher education service quality in Thailand. Procedia-Social and Behavioral Sciences, 116, 1088-1095. DOI: 10.1016/j.sbspro.2014.01.350

Received: 2020-04-15

Revision requested: $2020-06-27$

Revised: 2020-07-19 (1 revision)

Accepted: 2020-08-25 


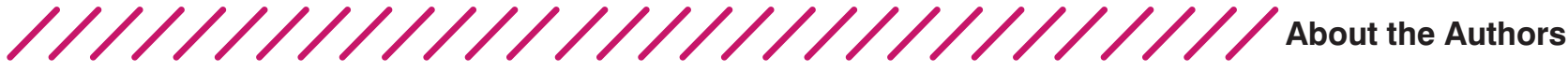

\section{Ana Jovičić Vuković \\ Novi Sad School of Business, Novi Sad, Serbia dr.ana.jovicic@gmail.com}

Ana Jovičić Vuković, PhD, is a lecturer at the Novi Sad School of Business. She completed her PhD studies in Tourism and Hospitality Management at the University of Novi Sad, Faculty of Sciences. She acquired a bachelor's and a master's degree at two different faculties in the fields of Tourism and Hotel Management and Business Economics. She worked as a research associate in international, national and provincial projects. She published more than 60 scientific papers in international journals and conferences in the field of tourism and hotel management.

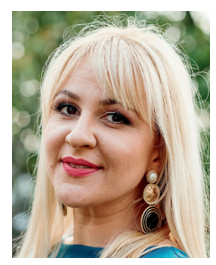

\section{Jelena Damnjanović \\ Novi Sad School of Business, Novi Sad, Serbia jdamnjanovic5@gmail.com}

Jelena Damnjanovic, PhD, completed her graduate studies in international economics

(MA and PhD) in Belgrade. Currently, she is the director of the Novi Sad School of

Business (Novi Sad, Serbia) and the professor of international business at the same School. Her major academic interests are in international economics, European Union and its enlargement, transnational corporations, foreign direct investments, globalisation, international trade and competition. Jelena is the author and co-author of four textbooks, more than 40 academic papers (including contribution to the Palgrave Encyclopaedia) and a participant in international and government projects.

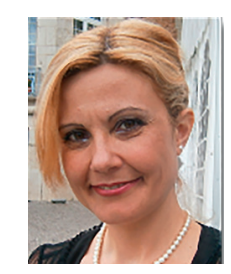

Nataša Papić-Blagojević Novi Sad School of Business, Novi Sad, Serbia npapic.blagojevic@gmail.com

Nataša Papić Blagojević, PhD, is a professor of applied business studies and Deputy Director for projects at the Novi Sad School of Business, the Republic of Serbia. Her fields of occupational interest are Economic Statistics and application of statistical methods in economic research. As a professor, she teaches several subjects, such as Quantitative Methods in Business, Financial and Actuarial Mathematics and Business Statistics. She completed her PhD studies at the University of Niš, Faculty of

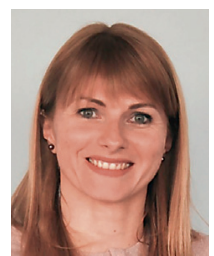
Economics, in June 2015. 